\title{
Oblivion and vengeance: Charles II Stuart's policy towards the republicans at the Restoration of 1660
}

\begin{abstract}
The Restoration of Charles II Stuart in 1660 was reckoned in post-revolutionary England both in terms of a long-awaited relief and an inevitable menace. The return of the exiled prince, whose father's disgraceful decapitation in the name of law eleven years earlier marked the end of the British monarchy, must have been looked forward to by those who expected rewards for their loyalty, inflexibility and royal affiliation in the turbulent times of the Interregnum. It must have been, however, feared by those who directly contributed to issuing the death warrant on the legally ruling king and to violating the irrefutable divine right of kings. Even though Charles II's mercy was widely known, hardly anyone expected that the restored monarch's inborn mildness would win over his well-grounded will to revenge his father's death and the collapse of the British monarchy. It seems that Charles II was not exceptionally vindictive and was eager to show mercy and oblivion understood as an act of amnesty to those who sided with Cromwell and Parliament but did not contribute directly to the executioner raising his axe over the royal neck. On the other hand, the country's unstable situation and the King's newly-built reputation required some firm-handed actions taken by the sovereign in order to prevent further rebellions or plots in the future, and to strengthen the position of the monarchy so shattered by the Civil War and the Interregnum.
\end{abstract}

Keywords: Restoration, Charles II, English Civil War, Oliver Cromwell, regicide.

\section{Introduction}

When in 1660 Charles II returned from his exile in France, many saw the Restoration of the House of Stuart as a chance to regain peace and order after the turbulent period of the Civil War and the Interregnum. For those who supported the King after his father had been beheaded and continued to fight against Cromwell's army, it was a sigh of relief and an obvious opportunity to be rewarded for their loyalty. Those who sided with the republicans and contributed to the overthrow and consequently the regicide must have felt unsure of their future and feared royal vengeance. The restored King's policy towards the rebels in the new political reality was hardly predictable and hard to be anticipated. Some believed that the new monarch would be much less lenient and merciful towards his and his father's enemies and would try to revenge those who triggered Charles I's 
disgraceful execution and the collapse of the House of Stuart in 1642. Charles II entered London on May 29th 1660 and, as Fraser says, this day "ushered in an age of anxiety as well as an age of rejoicing" (187).

The paper looks at Charles II's policy towards those who sided with the parliamentarians and those who signed his father's death warrant. Its major aim is to look at selected events that took place at the Restoration in order to define the policy towards republicans that Charles II exercised upon his arrival in England, and to try to understand the criteria and reasons hidden behind the royal decisions to punish and to pardon.

\section{Oblivion and mercy}

When Charles II was restored to the throne, one of his supporters - the poet John Dryden praised the great return in a panegyric called "Astrea Redux" (10), where he clearly hopes that the new reign will be marked by mercifulness rather than vindictiveness:

\footnotetext{
But you, whose Goodness your Descent doth show,

Your Heav'nly Parentage and Earthly too;

By that same mildness which your Fathers Crown

Before did ravish, shall secure your own.

Not ty'd to rules of policy, you find

Revenge less sweet than a forgiving mind.

Thus, when th' Almighty would to Moses give

A sight of all he could behold and live;

A voice before his Entry did proclaim

Long-Suffring, Goodness, Mercy in his Name.

Your Pow'r to Justice doth submit your Cause,

Your Goodness only is above the Laws. (256-267)
}

The poet, who was a close observant of the turmoil of the Civil War, notes that Charles I's mildness was something that his son should take over in his dealings with the rebels. Moreover, he suggests that forgiveness will be more beneficial and advantageous to the King than the potential revenge.

Indeed, the King did not seem to be taking pleasure in punishing those who violated the divine right of kings by deposing and decapitating his father 11 years earlier. It was not only Dryden who pinpointed the King's mercifulness as his great merit. Historians also pay attention to Charles II's conciliatory approach towards those who rebelled: "In his determined mercy, King Charles in 1660 did show himself indeed a veritable olive-branch-bearing dove" (Fraser, 187). Fraser (187) also notes that the peaceful image of the King was based upon his will to follow two paths of his policy towards those engaged in the Civil War: reward and conciliation. His policy was to reward those royalists who suffered exile, imprisonment or physical wounds during the War and the Interreg- 
num, and to reconcile with the Cromwellians. Hutton says that "the charitable view of Charles's reactions is that they reveal a remarkable moderation and self-restraint. The skeptical one is that he found it easy to forgive individual English republicans because he had no personal grudges against them" (141). Hutton gives an example of Charles's mercy when he followed the advice of the House of Commons, who suggested reprieving the republican general John Lambert and the politician Sir Henry Vane, who were exposed to death by the House of Lords (141). The King's forgiving attitude towards Lambert may seem exceptionally generous as, according to C.P. Hill, "among the Parliamentarian commanders only Fairfax and Cromwell were more gifted soldiers [than Lambert]" (167). If Lambert was the third most responsible person for ruining the House of Stuart, then why would the King have pardoned him? The answer might be quite complex. First of all, Lambert "was less disliked by the Royalists than most of the Parliamentarian leaders" (167) because he was not a Puritan. Secondly, he was out of London on the day of the King's execution, which might suggest that he did not fully support or accept the idea of the King's condemnation to death. In fact, he was not among those 59 regicides who signed the death warrant on King Charles I. Thirdly, "he opposed the proposals to make Cromwell king and the Protectorate hereditary, and this action ... led to a breach and to his dismissal" (Hill, 168). Therefore, it is easy to understand the King's inclination to spare Lambert's life and to punish him only by sentencing him to life imprisonment. Vane's case is much more complicated. In spite of being an influential politician whose persuasive speeches spurred the collapse of the English monarchy, he "was no ardent supporter of the Army ... and he played no part in the King's trial or in the events leading to it" (116). When the parliament passed the Indemnity and Oblivion Act in order to minimize the vengeance for the actions taken during the Interregnum, Vane was excluded from oblivion and treated as an exception, together with those who were directly involved in the King's death. Vane was imprisoned in 1660 in the Tower until parliament petitioned the King to grant mercy to the politician, which the monarch took advantage of and accepted. Vane himself, however, turned the tide against himself when during his trial at court he "chose to defend himself by vindicating parliamentary sovereignty" (117) and undermined the King's de jure possession. This made the King realize that Vane was not only dangerous to the restored monarchy in his views but also unwilling to show repentance for his republican support during the Civil War. In such a case, the King could not allow his name to be shattered and accused of exercising excessive mercy to those who were not even eager to bend and apologize for their previous political siding. Charles could not do anything else but to go back on his word, and Vane was sentenced to death. Although he was supposed to be hanged, drawn and quartered, the King's inborn mildness let him muster up his last act of mercy towards Vain and grant him the gentleman's death of beheading. Hence, one might have the impression that Vane "was charged with treason against Charles II rather than against Charles I" (Fraser, 185). Samuel Pepys's account on Vane's execution is also quite telling as for the King's attitude towards the convict: "The King had given his body to his friends; and, therefore, he told them that he hoped they would be civil to his body when dead; and he desired they would let him die like a gentleman and a Christian, and not crowded and pressed as he was" (66). 
Both historians and eyewitnesses seem to note and highlight the King's forgetful policy. In fact, ten years after the Restoration "he was accepting hospitality from Henry Cromwell, second son of the late Protector, at his home near Newmarket" (Fraser, 186). What is more, the King sought conciliation of the Cromwellians and resolved that "service during the Interregnum should be no disqualification" (190). This rule was, for instance, applied to Sir Matthew Hale and Edward Atkins. Hale and Atkins were renowned judges under the Protectorate and the Commonwealth who accepted the Parliamentarian regime. This, however, did not discourage the King from reappointing them to the their posts as he valued their integrity and even-handedness.

The most convincing argument for acknowledging Charles's merciful and mild character lies in his dealings with some of the regicides. Even though he had the power to revenge his father's death by executing all living signatories of the death warrant, he did not resolve to do so. Fraser's account of the King's policy towards the regicides shows Charles as a merciful monarch: "Of the forty-one surviving regicides, those who had signed the warrant and a few others closely associated with the King's death as well as the two (unidentified) executioners of Charles I, twelve died altogether. It was the King who prevented a further nineteen of their number" (185).

The issuance of the Indemnity and Oblivion Act in 1660 confirmed the resolutions of the Declaration of Breda. The Act promised amnesty and pardon to Cromwellians excluding fifty individuals, of whom thirteen were executed. If one remembers that there were fifty-nine signatories of the death warrant on King Charles I, eleven commissioners who did not sign it, but were involved in the process, twelve officers at the court trying Charles I, and eleven other associates, then thirteen executions seems to be a symbolic punishment. When only the fifty-nine regicides are taken into account, only eight of them were executed (or died awaiting execution), whereas nineteen were given life sentences. Six out of the nineteen (Peter Temple, Henry Smith, Augustine Garland, Gilbert Millington, Robert Lilburne, Robert Tichborne) were first sentenced to death, but this was later commuted to life imprisonment.

Charles II, in historians' and eyewitnesses' views, was "never a personally vindictive man" (Fraser, 185) and in his policy towards the rebels he did not turn out to be like the mythological Orestes, who revenged his father Agamemnon by killing his murderers (185).

\section{Vengeance and remembrance}

In 1661, when Charles II was crowned, John Dryden, now appointed the Poet Laureate, once more referred to the King's policy towards the republicans in the panegyric "To His Sacred Majesty" (13):

Among our crimes oblivion may be set,

But 'tis our Kings perfection to forget. (87-88)

Here, Dryden seems to imply that although it is the Kings' right to forget and forgive, excessive mercy and oblivion might be dangerous and even perceived as a crime against the country. In fact, the King did not need to rely on the poet's advice to know that mercy and forgiveness should have 
limits, otherwise the royal grandeur and authority might be considerably diminished or jeopardized. Therefore, Charles's "temperamental disinclination to vengeance was not at all the same thing as an inclination to forget the past" (Fraser, 186).

Charles II, as a newly restored monarch, whose primary role was to restore peace and order in the mayhem of post-revolutionary England, could not afford to forgive all his and his father's enemies and forget all their sins. The violation of the divine rights of kings was, in fact, a violation of the fundamental principles which the country was built upon. Moreover, the fact that such an unthinkable and unprecedented coup de etat did happen in 1649 meant it might happen again in the future. Revolutions are generally not very frequent, but when they do occur they usually make people realize that the overthrow of a monarch or, at least, quick and sudden political turbulence is possible and might be used as a tool to warn a disobedient king again. Therefore, Charles II's mercy and oblivion had to be limited to an extent allowing the people to appreciate the King's great mercifulness towards his father's executors, but, on the other hand, notice his firmness, strength, and authority which would scare off potential revolutionists.

Fraser claims (186) that an atmosphere of fear and uncertainty was present at the King's court: "Revolution and its possible consequences, was one spectre which stalked the corridors of the King's palace from the inception of his reign to its end... But at no point was the presence of such a threatening ghost felt more acutely than in the early 1660s. "There was a general readiness and alertness to prevent criticism and dissatisfaction of those who had not yet got accustomed to the restored monarchy from turning into another rebellion and consequently a revolution:

Thus one finds the implicit fear of another revolution expressed continuously and in all sorts of different ways in the early years of the reign. There were significant details such as the preference for Windsor Castle as a royal fortress ... because it was properly garrisoned. There were broader policies, such as the concentration on forming a proper body of guards to surround the monarch ... A general jumpiness animated surveys of the careers of those with regicide connections. (Fraser, 186)

Such an overwhelming atmosphere of distrustfulness and invigilation did not allow the exercise of excessive mercy and risk being perceived as weak, thus an easy obstacle to be got rid of. In order to make the King appear powerful and yet forgiving but remembering, the dealings with the key regicides had taken a much rougher path. The punishment for Oliver Cromwell, Henry Ireton, and John Bradshaw were aimed to manifest the King's sturdiness and to send a clear message to all those who conspired and plotted against the restored monarchy. The posthumous executions of the three leaders were to demonstrate that Charles II's mercy was limited and did not apply to those who directly violated the divine right of kings. It was supposed to reiterate the fact that the King's memory of his late father was still vivid. As there is no question of doubt as for Cromwell, who was believed to have orchestrated the regicide, the choice of Ireton and Bradshaw needs to be reflected upon.

Ireton commanded the left wing at the momentous battle of Naseby in 1645, where he "fought like a lion" (Hill, 141). He is frequently reported to have been brave, competent and to have had a 
considerable influence "on the slower and far less clear mind of Cromwell" (142). In 1647 he was the major architect of the Heads of the Proposals - the settlement offered to Charles I. When the proposals were consecutively being rejected by the King, it was Ireton who willingly advocated the idea of bringing Charles I to trial. What is most justifying about the choice of Ireton to be posthumously executed was his personal engagement in writing the Remonstrance of Army - a statement about the regicide, his active part in the King's trial, his signature on the death warrant, and most importantly the fact that he was the son-in-law to Cromwell himself.

Bradshaw's fault seems to be even more evident. He became a prosecutor on behalf of Parliament at the time of the Civil War, and was "a competent and reasonable choice, if not a notably distinguished one, for membership of the commission set up by the Rump [Parliament] to try the King" (166). His role as President of the High Court of Justice for the trial of King Charles I was widely reverberating. Edward Hyde, Earl of Clarendon, who witnessed the trial, described Bradshaw as the one who administered the office "with all the pride, impudence, and superciliousness imaginable" (Clarendon, 327).

Cromwell, Ireton, and Bradshaw embodied audacity and tenacity in trying and, as a result, executing Charles I. Therefore, having all three perpetrators dead (Cromwell died in 1658, Ireton in 1651, and Bradshaw in 1659), the newly restored King could not let them rest in peace and ordered their posthumous executions. To make them even more symbolic and hence meaningful, the executions were scheduled on 30th January 1661, exactly twelve years after the infamous regicide had taken place. All three signatories of the late King's death warrant were disinterred, hanged at Tyburn and decapitated. Their bodies were thrown into a pit and their heads were placed on spikes and displayed at the end of Westminster Hall facing the direction of the place where Charles I had been executed.

The executions were reported by eye-witnesses who must have perceived the event as exceptionally significant. Samuel Pepys does not mention any other punishments for the regicides as frequently as he does in case of these three. On 30th January 1661, Pepys reports: "then to my Lady Batten's; where my wife and she are lately come again from being abroad, and seeing of Cromwell, Ireton, and Bradshaw hanged and buried at Tyburn" (43). Six days later Pepys returns to the subject, writing: "my wife and I by water to Westminster. Into the Hall and there saw my Lord Treasurer ... go up to the Treasury Office and take possessions thereof; and also saw the heads of Cromwell, Bradshaw, and Ireton, set up upon the further end of the Hall” (44). Even though Pepys's report seems to be a little laconic, it is still crucial that the diarist considered the event to be worth mentioning, and exposed the three names twice in his diary while enumerating the other chores and duties of his routine, everyday life. John Evelyn offers a much more lively and descriptive account of the executions:

This day (o the stupendious \& inscrutable Judgements of God) were the Carkasses of that arch-rebell Cromwell, Bradshaw the Judge who condemned his Majestie \& Ireton, sonn in law to the Usurper, dragged out of their superbe Tombs (in Westminster among the Kings), to Tyburne, \& hanged on the Gallows 
there from 9 in the morning til 6 at night, \& and then buried under that fatal \& ignominious Monument, in a deepe pitt: Thousands of people (who had seene them in all their pride \& pompous insults) being spectators: looke back at November 22: 1658 be astnosh'd - And (fear) God \& honor the King, but meddle not with them who are given to change. (Evelyn, 380)

What seems important in Evelyn's report is the symbolic relocation of the three regicides' bodies from the "superb Tombs" to the "ignominious monument in a deep pit." The chronicler reminds his readers of Cromwell's funeral on 22nd 1658 and warns not to "meddle with" Gods and Kings' divine rights. Evelyn highlights the most probable reason why Charles II resolved to have the bodies exhumed and publicly defamed. It was not pure and uninhibited vengeance that drove the King in disturbing the dead Cromwellians but to make the memory of his father endless and durable. The three heads now spiked and gazing at those visiting Westminster Hall were to make sure that nobody forgot the regicide, the revolution and the Protectorate and all their burdensome aftermaths. They also served to discourage those who considered another dethronement and those who missed the Republic.

The list of those who were to be posthumously executed included yet another name - Thomas Pride. He was one of those officers who were outstandingly hostile to the House of Commons in 1647. He carried out the "Purge" in 1648, "which immortalized his name" (Hill, 145), and, most importantly, he signed the death warrant on King Charles I. He died in 1658 and was also earmarked to share the fate of Cromwell, Ireton, and Bradshaw, but his execution was not carried out. Although it is difficult to guess the reason for his posthumous reprieve, it may lie in the fact that it was Pride who instigated "the officer's petition to which finally determined Cromwell not to take the Crown" (145).

Apart from the symbolic but still spectacular posthumous executions of the principal leaders of the regicide, there was a list consisting of those who were sentenced for life and those who were indeed quite cruelly lost. Adrian Scrope, Gregory Clement, and Thomas Harrison were all hanged, drawn, and quartered. Both Scrope and Clement were executed because they were among the judges who tried the King and signed the death warrant. Harrison, however, lost his life because apart from being one of the fifty-nine commissioners, he posed some real danger to the newly restored monarchy. He was one of the most skilful and eminent Cromwellian generals actively participating in the battles of Marston Moore, Naseby, and Preston, and it was he who "guarded Charles on his last journey to London" (Hill, 171). What must have worried Charles II, however, was that Harrison was a leader of a nonconformist dissenting group called the Fifth Monarchists (or Fifth Monarchy Men), who believed that "the vision of Daniel was about to be fulfilled, when the saints of the Most High would possess the kingdom for ever and ever" (171). As Cromwell's Protectorate set up in 1653 constituted the contradiction of Harrison's visions, he "lost his commission, declined to serve the Protectorate, and was twice imprisoned in Oliver's later years" (171). Even though, he must have posed a threat to the newly restored King for a number of reasons, he still believed in Daniel's prophecy and was awaiting the year 1666, which he believed had some 
relationship with the biblical Number of the Beast. If, according to the prophecy, the year 1666 was to put an end to the earthly rule of human beings and replace it with the Second Coming of the messiah, then the King might have suspected that Harrison would plot against him and the monarchy to facilitate the fulfilment of the prophecy he promoted and advocated so strongly. Such suspicions were well-grounded as Harrison decided not to flee England even when he knew that his fate had already been sealed. Therefore, the King's decision to hang, draw, and quarter Harrison had a more preventive than revengeful background.

\section{Conclusions}

What best defines and determines the King's dealings with his father's enemies after the Restoration in 1660 is his attitude towards Thomas Fairfax. Once the commander-in-chief in the Civil War and the most influential officer in revolutionary England, who indeed greatly contributed to the King's disposal, he refused to sign the death warrant and hence was given a royal pardon and kept his titles. Moreover, it was he who "was sent to invite Charles II to return, he welcomed the Restoration - although characteristically, he was deeply angered by the disinterment and gibbeting of Cromwell's corpse" (Hill, 133). It seems, then, that it was not the sheer participation or leadership in the military actions of the Civil War that was the criterion whether to punish or to reprieve, but the ability or disability to rehabilitate and to redeem one's sins committed against the monarchy.

It might also seem plausible that Charles II, as a prudent politician, had orchestrated to implement the "divide and rule" strategy in his policy to gain, maintain and reinforce his authority. Therefore, he resolved to punish selected Cromwellians and to spare the others in order to prevent the republicans from linking up, and to spur rivalries and foment discord among those who had sided with Cromwell a few years earlier. Moreover, despite his mild character, Charles could not afford to acquit those who had tried his father and hence directly violated the divine rights of kings that the Stuarts had been advocating so firmly. Therefore, the restored King had to face a difficult challenge by keeping the balance between conciliation with the Cromwellians and punishing the chief ringleaders and perpetrators of the temporary fall of the House of Stuart in order to highlight his own firmness and prevent future revolutions.

The quoted verses from Dryden's “To His Sacred Majesty" reiterate the King's "perfection to forget." This pampering tone of the Poet Laureate serves to highlight Charles's merciful approach to some of his enemies and to foreground his greatness as a monarch who brings back peace, order and justice to a country tormented by revolution. In the following lines Dryden makes it clear that peace is the ultimate purpose of the King's policy towards the republicans, and this may be achieved only if the monarch proves to be forgiving:

Virtues unknown to these rough Northern climes

From milder heav'ns you bring, without their crimes:

Your calmnesse does no after storms provide,

Nor seeming patience mortal anger hide. (89-92) 
As in the earlier poem "Astrea Redux," Dryden claims that the King's "mildness, calmness, and patience" are "the royal virtues necessary for domestic tranquillity" (Garrison 1975, 171). Although Dryden's praise may be read as advice to Charles for the future, the King seemed to have already been aware that peace was what the people of Britain longed for after years of political instability. In order to achieve it, the newly-crowned monarch had to find an equilibrium between forgetting and remembering, between forgiving and punishing.

Fraser's description of the King's return to England in an age of anxiety and rejoicing synthesizes the above argument: "Yet with these twin provisions of watchfulness against the repetition of revolution and concern for justice to his father's memory, Charles II arrived in a healing mood" (187).

\section{References:}

Dryden, John. 1959. The Poems of John Dryden. London: Oxford University Press.

Evelyn, John. 2006. The Diary of John Evelyn. London: Everyman's Library.

Fraser, Antonia. 2002. King Charles II. London: Phoenix Press.

Garrison, James. D. 1975. Dryden and the Tradition of Panegyric. Berkeley and Los Angeles: University of California Press.

Hill, C.P. 1988. Who's Who in Stuart Britain. London: Shepheard-Walwyn.

Hutton, Ronald. 1989. Charles II Oxford: Clarendon Press.

Hyde, Edward, Earl of Clarendon. 2009. The History of Rebellion. New York: Oxford University Press.

Pepys, Samuel. 2003. The Diary of Samuel Pepys. New York: The Modern Library. 